\title{
"DAILY COPING BEHAVIOR PADA KELOMPOK MAHASISWA PENDIDIKAN VOKASIONAL KESEJAHTERAAN KELUARGA UNIVERSITAS NEGERI JAKARTA DALAM PRAKTEK MANAJEMEN SUMBERDAYA KELUARGA"
}

\author{
Dimas Teguh Prasetyo \\ Email: dimasteguh2394@gmail.com \\ Program Studi Psikologi Terapan, Fakultas Psikologi Universitas Indonesia
}

\begin{abstract}
Abstrak
Program Manajemen Sumber Daya Keluarga merupakan salah satu mata kuliah wajib peminatan ilmu keluarga di program studi Pendidikan Vokasional Kesejahteraan Keluarga Universitas Negeri Jakarta. Mata kuliah MSDK menerapkan tingkat kedisiplinan serta profesionalitas yang tinggi. Kelompok mahasiswa yang bertugas diwajibkan mematuhi segala peraturan Lab MSDK. Kelompok mahasiswa yang mengikuti MSDK memerlukan pengelolaan stress dan pemecahan masalah yang baik. Hal tersebut diperlukan karena setiap harinya mereka akan menemukan sumber-sumber stres mulai dari perbedaan kepribadian teman satu kelompoknya, hubungan interpersonal antar anggota MSDK hingga perbedaan kebiasaan yang sering ditampilkan didalam rumah masing-masing. Oleh karena itu, perilaku coping akan membantu para mahasiswa dalam mengelola sumber stress selama berada di Lab MSDK. Tujuan dari penelitian ini untuk mengetahui dan menganalisis strategi koping para mahasiswa PVKK UNJ yang sedang mengikuti program MSDK. Adapun hasil menunjukan bahwa mahasiswa lebih banyak menggunakan strategi koping relaksasi dan katarsis untuk mengurangi adanya sumber stress selama program MSDK. Sementara itu, limitasi dan rekomendasi akan dibahas lebih lanjut dalam studi ini.
\end{abstract}

Kata Kunci: Daily Coping Behavior, Mahasiswa PVKK UNJ, Program MSDK

\begin{abstract}
The Family Resources Management Program is one of the compulsory subjects for specialization in family science in the study program of Family Welfare Vocational Education, Jakarta State University. MSDK courses apply a high level of discipline and professionalism. The group of students in charge is required to comply with all the rules of the MSDK Laboratorium. The group of students participating in MSDK requires good management of stress and problem solving. It is necessary because every day they will find sources of stress ranging from differences in personality of one group, interpersonal relationships between MSDK members to differences in habits that are often displayed in their homes. Therefore, coping behavior will assist students in managing stress resources while at the MSDK Laboratorium. The purpose of this study was to find out and analyze coping strategies of students of PVKK UNJ who were taking the MSDK program. The results show that they were more use relaxation and catharsis coping strategies to reduce the source of stress during the MSDK program. Meanwhile, limitation and recommendations will be discussed further in this study.
\end{abstract}

Keywords: Daily Coping Behavior, Student of PVKK UNJ, MSDK program 


\section{PENDAHULUAN}

Program Manajemen Sumber Daya Keluarga (selanjutnya disingkat MSDK) merupakan salah satu mata kuliah wajib peminatan ilmu keluarga di program studi Pendidikan Vokasional Kesejahteraan Keluarga Universitas Negeri Jakarta (selanjutnya disingkat PVKK UNJ). Mata kuliah ini memiliki bobot sebesar 4 sks dengan cakupan perkuliahan $100 \%$ praktek lapangan (Buku Pedoman Akdemik Fakultas Teknik UNJ, 2016). MSDK merupakan salah satu komponen penting dalam kompetensi yang harus dimiliki oleh setiap mahasiswa PVKK UNJ. Mahasiswa akan membuat kelompok terdiri dari maksimal tujuh orang dengan komposisi perempuan dan laki-laki. Selanjutnya mahasiswa PVKK UNJ yang telah terbentuk dalam 1 kelompok akan tinggal di laboratoriun MSDK UNJ yang berada di belakang kampus A UNJ Rawamangun selama satu bulan ditemani dengan satu dosen pria dan satu dosen perempuan yang tinggal disamping Lab MSDK. Kegiatan inti dari MSDK yakni mengaplikasikan beberapa keilmuan yang telah didapat selama perkuliahan seperti table manner, house keeping, pemberdayaan sumberdaya keluarga, pengantar ekonomi keluarga, kewirausahaan, teknik komunikasi, industri kreatif, ilmu sosial budaya, pertamanan, dekorasi dan penataan ruang serta ilmu kesejahteraan keluarga. Laboratorium MSDK UNJ berbentuk rumah dengan tujuh kamar tidur, empat kamar mandi, dua ruang keluarga, dua ruang tamu, teras rumah, kedai keluarga, serta didukung dengan fasilitas kitchen set dan laundry. Laboratorium MSDK memang diatur seperti rumah agar mahasiswa merasakan kondisi rumah sebenarnya yang menjadi dasar pengaplikasian ilmu yang telah dipelajari selama mengikuti perkuliahan di program studi PVKK UNJ.

Mata kuliah MSDK menerapkan tingkat kedisiplinan serta profesionalitas yang tinggi. Kelompok mahasiswa yang bertugas diwajibkan mematuhi segala peraturan Lab MSDK. Mereka dituntut menjaga kebersihan Lab MSDK setiap hari, mengatur menu makanan, mengelola keuangan keluarga dari penjualan makanan di kedai keluarga, membuat social project di masyarakat sekitar, melaksanakan praktek table manner hingga pelaksanaan gathering keluarga ke suatu tempat. Hal tersebut dilakukan bertahap mulai dari pembuatan proposal sebelum masuk kedalam Lab MSDK, pembagian peran anggota keluarga selama masa MSDK secara bergantian dan diakhiri dengan menyusun laporan MSDK. Setiap harinya mereka harus memastikan semua kegiatan berjalan dengan baik mulai dari pagi hingga malam hari. Segala hal yang dilakukan oleh kelompok tersebut akan dipantau langsung oleh Kepala Lab MSDK yang akan menilai proses hingga luaran mata kuliah ini.

Kelompok mahasiswa yang mengikuti MSDK memerlukan pengelolaan stress dan pemecahan masalah yang baik. Hal tersebut diperlukan karena setiap harinya mereka akan menemukan sumbersumber stres mulai dari perbedaan kepribadian teman satu kelompoknya, hubungan interpersonal antar anggota MSDK hingga perbedaan kebiasaan yang sering ditampilkan didalam rumah masingmasing. Faktor waktu yang cukup lama untuk menetap dalam Lab MSDK juga diduga memberikan kontribusi sebagai sumber stress. Respon individual dalam menanggulangi perubahan hidup yang dapat menimbulkan masalah biasa dikenal dengan istilah coping behavior (Wibowo, 2011). Oleh karena itu, perilaku coping akan membantu para mahasiswa dalam mengelola sumber stress selama berada di Lab MSDK.

Coping Behavior atau juga dikenal dengan coping merupakan usaha-usaha baik kognitif maupun perilaku yang bertujuan untuk mengelola tuntutan lingkungan dan internal, serta mengelola konflik-konflik yang mempengaruhi individu (Coyne, Aldwin \& Lazarus, 1981). Coping memiliki banyak tujuan termasuk mengelola mood yang negatif dan stressor yang mampu mempengaruhi mood (Folkman \& Moskowitz dalam Friedman, 2016). Secara umum banyak peneliti dari tahun 1980 an yang mendefinisikan coping sebagai konstruk yang ditampilkan untuk menghadapi stres di sekitarnya termasuk stres yang berkaitan dengan pekerjaan, penyakit dan masalah lingkungan (Latack \& Havlovic, 1992). Adapun perilaku coping yang paling banyak digunakan yakni merujuk pada kategori yang dibuat oleh Folkman dan Moskowitz yakni problem-focus coping, emotion-focus coping, dan meaning-focus coping (Kloss., dkk, 2012). Problem-focus coping yakni coping yang 
ditujukan dengan adanya tindakan langsung dalam mengatasi masalah seperti membuat perencanaan dan menjalankan rencana tersebut. Emotion-focus coping merujuk pada coping yang ditujukan dengan menampilkan emosi dalam menghadapi stressor. Adapun cara yang biasa dilakukan seperti mencari dukungan dari teman, keluarga atau orang terdekat. Sedangkan meaningfocus coping ditujukan dengan menemukan signifikansi pada value yang terkandung dalam sebuah stressor. Hal tersebut dilakukan dengan menyadari kesalahan, mendekatkan diri pada hal-hal yang bersifat spiritual dan sebagainya. Ketiga kategori tersebut dapat saling berinteraksi tergantung pada konteks stressornya dan cara orang dalam menghadapi sebuah masalah.

Dalam konteks permasalahan sumber stress yang dihadapi oleh kelompok mahasiswa di dalam Lab MSDK, penyesuaian diri dioperasionalisasikan sebagai bentuk strategi dan manajemen diri dalam menyelesaikan tugas yang harus dikerjakan setiap harinya. Hal tersebut memberikan definisi pada masalah yang dihadapi merupakan masalah yang sebenarnya muncul dalam kehidupan seharihari. Dimana pekerjaan seperti membersihkan rumah, memasak, dan mengelola sumberdaya keluarga lainnya merupakan kompetensi yang harus dikuasai oleh seorang mahasiswa lulusan PVKK UNJ. Kegiatan domestik yang banyak dianggap orang sebagai kegiatan yang ringan, sebenarnya memiliki potensi stresor yang besar jika dilakukan secara rutin dan dalam jangka waktu yang panjang (seperti halnya yang dilakukan setiap hari oleh ibu rumah tangga). Oleh karena itu, peneliti membatasi perilaku coping secara khusus kedalam daily coping behavior.

Daily coping behavior merupakan konstruk coping yang merujuk pada upaya individu dalam menghadapi masalah dalam jangka waktu yang panjang (Stone \& Neale, 1984). Konstruk tersebut terdiri dari delapan dimensi yakni distraction (gangguan), situation redefinition (mengatasi masalah dengan sudut pandang yang lebih positif), direct action (tindakan langsung), catharsis (katarsis), acceptance (penerimaan diri), seeking social support (mencari dukungan sosial), relatation (relaksasi diri), religion (religiusitas). Kedelapan dimensi tersebut digambarkan sebagai dimensi yang dapat digunakan dalam menghadapi masalah yang muncul sehari-hari dan dalam jangka waktu yang cukup panjang (minimal 1 minggu). Pada salah satu penelitian, daily coping behavior berkorelasi negatif dengan neuroticisim pada mahasiswa (Gunthert, Cohen, \& Armeli, 1999). Oleh karena itu, peneliti membatasi masalah pada cara atau perilaku coping yang muncul pada mahasiswa PVKK UNJ dalam menghadapi masalah domestik di dalam Lab MSDK selama 1 minggu.

\section{METODOLOGI}

Kelompok mahasiswa Pendidikan Vokasional Kesejahteraan Keluarga Universitas Negeri Jakarta yang sedang praktek di Laboratorium Manajemen Sumber Daya Keluarga (MSDK). Anggota kelompok berjumlah tujuh mahasiswa perempuan yang berasal dari angkatan 2014. Pengambilan data dalam tugas ini menggunakan teknik observasi atau pengamatan. Adapun teknik observasi merupakan teknik pengambilan data yang disusun secara sistematis dengan melakukan pengamatan terhadap gejala-gejala spontan yang muncul sebagai indikator dari perilaku yang diamati (Indrawati, 2017). Alat ukur yang digunakan dalam teknik observasi ini mengacu pada pengertian coping behavior dan delapan dimensinya yang dibuat oleh Stone dan Neale (1984). Untuk kepentingan penyusunan lembar observasi, peneliti juga telah melakukan elisitasi lapangan ke Laboratorium MSDK UNJ pada hari Selasa, 13 Maret 2018. Adapun dalam pengambilan data, peneliti mengambil posisi covert observer atau pengamat yang tidak memberitahukan tujuan dari keberadaanya adalah untuk mengamati gejala dari perilaku partisipan. Peneliti juga telah mendapatkan izin untuk tinggal beberapa hari di Lab MSDK UNJ.

\section{HASIL DAN PEMBAHASAN}

\section{Waktu pengamatan dan karakteristik subjek pengamatan}

Observasi dalam melihat perilaku daily coping pada kelompok mahasiswa PVKK UNJ dilakukan selama tiga hari yakni 22,23 dan 26 maret 2018. Pengamatan dilakukan di sekitar area laboratorium 
MSDK UNJ di Komplek Perumahan Daksinapati, Rawamangun Muka, Jakarta Timur. Peneliti mengadakan pengamatan pada waktu pagi hingga sore hari yakni sekitar $09.00-18.00$ WIB. Kelompok mahasiswa PVKK UNJ yang mengikuti praktikum MSDK kali ini berjumlah 7 orang perempuan. Semua mahasiswanya berasal dari angkatan 2014 atau masuk dalam semester 8 saat ini. Salah satu dari mereka telah bekerja sebagai staf magang Dinas Sosial Jakarta Timur, sedangkan tujuh lainnya fokus dengan persiapan seminar proposal skripsi. Untuk kepentingan etika penelitian, peneliti tidak memberitahukan maksud dan tujuan pengamatan di awal pengamatan. Namun, peneliti memberikan debriefing pada subjek yang diamati setelah pengamatan selesai di hari yang ketiga. Semua data yang diambil oleh peneliti dalam pengamatan ini juga telah mendapatkan persetujuan oleh para subjek penelitian dan Kepala Laboratorium MSDK UNJ.

\section{Identifikasi sumber masalah (stresor)}

Pengamatan ini dilakukan untuk menggali perilaku daily coping kelompok mahasiswa PVKK UNJ dalam menghadapi stesor yang hadir selama masa praktikum di laboratorium MSDK UNJ. Beberapa stresor atau sumber masalah juga dapat diidentifikasi sebagai faktor yang menimbulkan kemunculan daily coping behavior pada mahasiswa selama proses pengamatan. Adapun beberapa stresor tersebut diantaranya sebagai berikut:

Tabel 1. Identifikasi sumber masalah yang muncul dalam proses pengamatan

\begin{tabular}{|l|l|l|}
\hline \multicolumn{1}{|c|}{ Hari ke-1 dari teman } & \multicolumn{1}{|c|}{ Hari ke-2 } & \multicolumn{1}{|c|}{ Hari ke-3 } \\
\hline $\begin{array}{l}\text { Teguran penggoreng ikan yang panas } \\
\text { kelompoknya }\end{array}$ & $\begin{array}{l}\text { Target penjualan pisang coklat } \\
\text { frozen untuk dana bakti sosial } \\
\text { dan family gathering }\end{array}$ \\
\hline $\begin{array}{l}\text { Pelanggan yang hadir di saat } \\
\text { jam makan siang }\end{array}$ & $\begin{array}{l}\text { Pelanggan yang hadir } \\
\text { menjelang tea time }\end{array}$ & $\begin{array}{l}\text { Pelanggan yang hadir di sela } \\
\text { jam makan siang }\end{array}$ \\
\hline Keran air yang bermasalah & $\begin{array}{l}\text { Teguran dari teman } \\
\text { kelompoknya }\end{array}$ & $\begin{array}{l}\text { Membeli bahan-bahan untuk } \\
\text { bakti sosial }\end{array}$ \\
\hline $\begin{array}{l}\text { Telpon dari dosen pembimbing } \\
\text { MSDK terkait persiapan family } \\
\text { gathering ke Bandung }\end{array}$ & $\begin{array}{l}\text { Target penjualan pisang coklat } \\
\text { frozen untuk dana bakti sosial } \\
\text { dan family gathering }\end{array}$ & $\begin{array}{l}\text { Belanja untuk keperluan kedai } \\
\text { keluarga }\end{array}$ \\
\hline $\begin{array}{l}\text { Target penjualan pisang coklat } \\
\text { frozen untuk dana bakti sosial } \\
\text { dan family gathering }\end{array}$ & & \\
\hline
\end{tabular}

Berdasarkan tabel 1 diatas diketahui bahwa setiap harinya para mahasiswa memiliki sumber masalah di dalam laboratorium MSDK. Masalah yang muncul tersebut beragam didasarkan pada kegiatan yang dilakukan selama praktikum MSDK. Terlihat juga bahwa salah satu masalah yang terjadi secara konsisten dalam proses pengamatan yakni adanya target penjualan pisang coklat frozen untuk dana bakti sosial dan family gathering. Penjualan pisang coklat frozen sebenarnya merupakan inisiatif yang dilakukan oleh para mahasiswa untuk dapat memenuhi kebutuhan mereka terhadap dana bakti sosial dan family gathering kedepannya. Dana yang mereka butuhkan pun cukup besar yakni Rp 1.000.000 untuk dana bakti sosial di panti asuhan dan Rp 3.000.000 untuk kegiatan family gathering yang wajib dilakukan sebelum mengakhiri praktikum MSDK. Untuk mencapai target pendanaan tersebut, para mahasiswa menjual pisang coklat frozen seharga Rp 30.000/bungkus. Usaha yang mereka lakukan ini ternyata menimbulkan masalah baru. Mereka harus memasarkannya ke teman dan pelanggan di kedai keluarga, mengantarkan pesanan ke pembeli dan mengambil ketersediaan barang dari agen frozen di daerah Rawamangun. Hal tersebut dianggap masalah baru karena menimbulkan usaha lebih diluar praktikum MSDK. Sebagai konsekuensinya, mereka harus saling membantu dan bekerjasama dalam menjual produk tersebut. 
Masalah lain yang muncul sebagai penyebab adanya perilaku daily coping pada mahasiswa adalah kegiatan sehar-hari yang dikerjakan di dalam laboratorium MSDK. Terbatasnya ruang pantau dan pengamatan yang dimiliki oleh peneliti, pada akhirnya hanya mampu menangkap beberapa sumber masalah yang terlihat dan terdengar di laboratorium MSDK. Sumber masalah tersebut dapat diidentifikasi mulai dari teguran teman, teguran dari dosen pembimbing MSDK melalui terlpon, kegiatan memasak, pelayanan di kedai keluarga dan kegiatan menjelang makan siang dan tea time. Hal tersebut memunculkan berbagai perilaku daily coping yang akan dibahas secara rinci pada pembahasan selanjutnya. Adapun terdapat sumber masalah yang diprediksi akan muncul dalam proses pengamatan tetapi faktanya tidak muncul yakni teguran langsung dari kepala laboratorium MSDK dan komentar yang biasa diberikan kepada mahasiswa. Ketidakhadiran kepala laboratorium MSDK selama proses pengamatan juga diduga memberikan kontribusi pada perilaku daily coping yang muncul.

\section{Analisis berdasarkan dimensi}

a. Dimensi distraction

Dimensi distraction atau dapat diartikan sebagai gangguan dan dioperasionalisasikan sebagai bentuk coping dengan mangalihkan perhatian dari masalah dengan memikirkan hal-hal lain atau terlibat dalam beberapa kegiatan. Sesuai dengan hasil pengamatan yang disajikan pada gambar 1 dapat diketahui bahwa tidak ada satupun perilaku dalam dimensi ini yang muncul dalam tiga hari proses pengamatan. Ketidakmunculan perilaku dalam dimensi ini sebenarnya sudah diprediksi sebelumnya oleh peneliti. Peneliti menelaah bahwa salah satu kelemahan gambaran perilaku dalam dimensi tidak cukup kuat untuk muncul sebagai perilaku yang dapat diobservasi. Dugaan bias yang terdapat dalam perilaku di dimensi ini bisa jadi menjadi salah satu faktor ketidakhadiran enam item perilaku tersebut. Hal tersebut juga dikarenakan intensi atau niat dibalik munculnya perilaku tersebut masih diragukan oleh dosen pembimbing. Enam item tersebut bisa jadi muncul bukan karena gangguan yang dimaksud, tetapi bisa jadi akibat faktor lain yang sifatnya unobserved. Dalam alat ukur aslinya, Stone dan Neale (1984) juga menggunakan self-report yang sifatnya penggambaran langsung perilakunya oleh analisis dan identifikasi dari individu yang mengalami sumber gangguan tersebut.

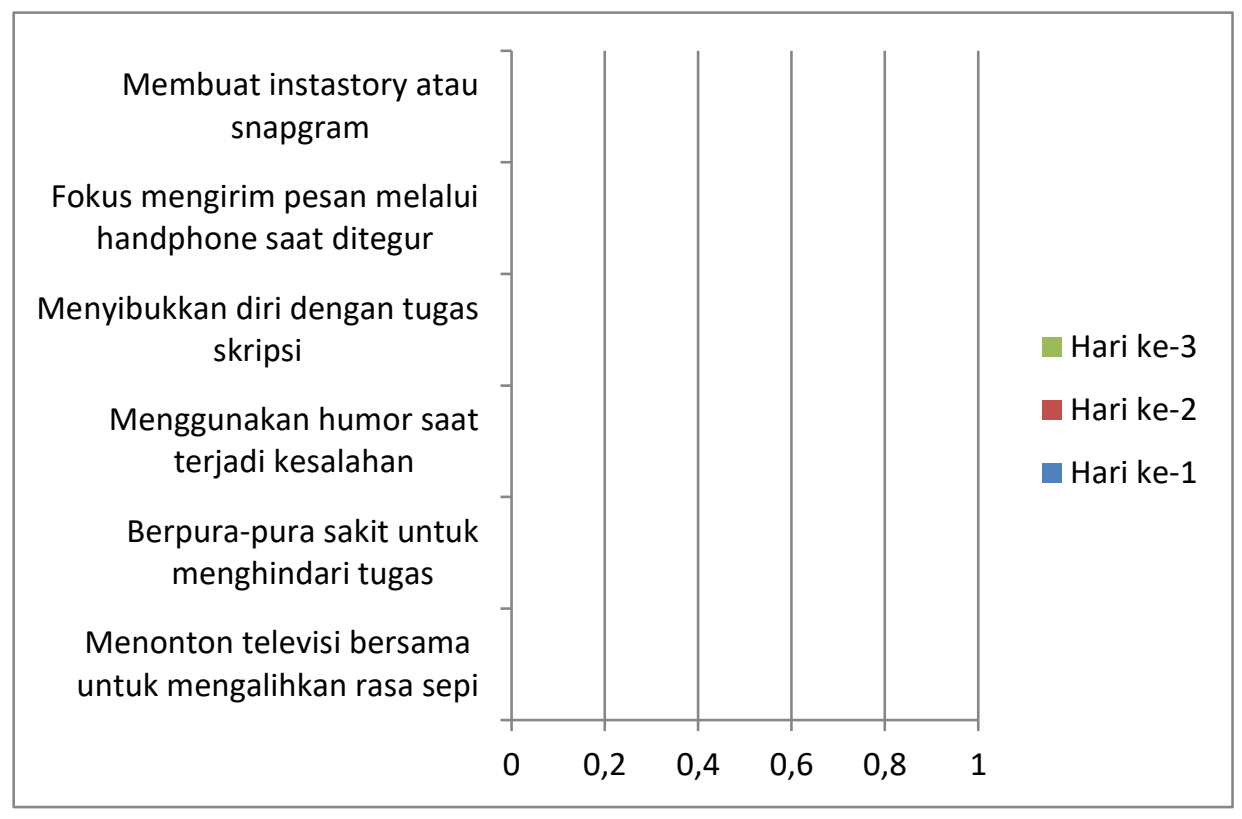

Gambar 1. Grafik sebaran frekuensi perilaku yang muncul berdasarkan dimensi Distraction 


\section{b. Dimensi situation redefinition}

Dimensi situation redefinition atau dapat diartikan sebagai mendefinisikan masalah sebagai suatu yang positif dan dioperasionalisasikan sebagai bentuk coping dengan mengatasi masalah dengan sudut pandang yang lebih positif. Sesuai dengan hasil pengamatan yang disajikan pada gambar 2 dapat diketahui bahwa hanya satu dari lima item perilaku yang muncul dan hadir di hari kedua yakni mencatat evaluasi kegiatan. Perilaku tersebut dilakukan oleh mahasiswa yang bertugas sebagai manager pada hari itu. Di hari kedua, salah satu masalah yang muncul adalah teguran dari teman kelompoknya. Teguran tersebut merupakan hasil kesalahan manager yang lalai menegur teman kelasnya yang berkunjung dan masuk tanpa izin manager. Sesuai dengan peraturan MSDK (terlampir), para mahasiswa yang sedang praktikum di laboratorium MSDK tidak memperbolehkan tamu untuk masuk kedalam Lab tanpa seizin manager. Hal tersebut dikhawatirkan akan menyebabkan hilangnya barang berharga di dalam Lab yang akan menjadi tanggung jawab manager yang bertugas hari itu. Perilaku teguran dari salah satu mahasiswa memang masuk akal karena memperingati akan keamanan Lab MSDK saat itu. Perilaku mencatat evaluasi di buku manager pada saat itu memang juga digunakan sebagai bukti laporan yang harus disampaikan di malam evaluasi setiap tiga hari sekali.

Rendahnya kemunculan item perilaku dalam dimensi ini juga mencatat bagi peneliti dalam mengkonstruk perilaku yang dapat secara operasional menggambarkan dimensi situation redefinition. Kuatnya penggunaan asumsi pendefinisian masalah yang sulit diobservasi juga dievaluasi sebagai salah satu kelemahan dalam dimensi ini. Kembali pada alat ukur aslinya, Stone dan Neale (1984) tidak mengoperasionalisasikan perilaku yang observable dalam dimensi ini. Hal ini memungkinkan adanya kerancuan dalam keyakinan peneliti dalam memastikan perilaku yang muncul merupakan sebab dari adanya pendefinisian masalah dengan sudut pandang yang lebih positif.

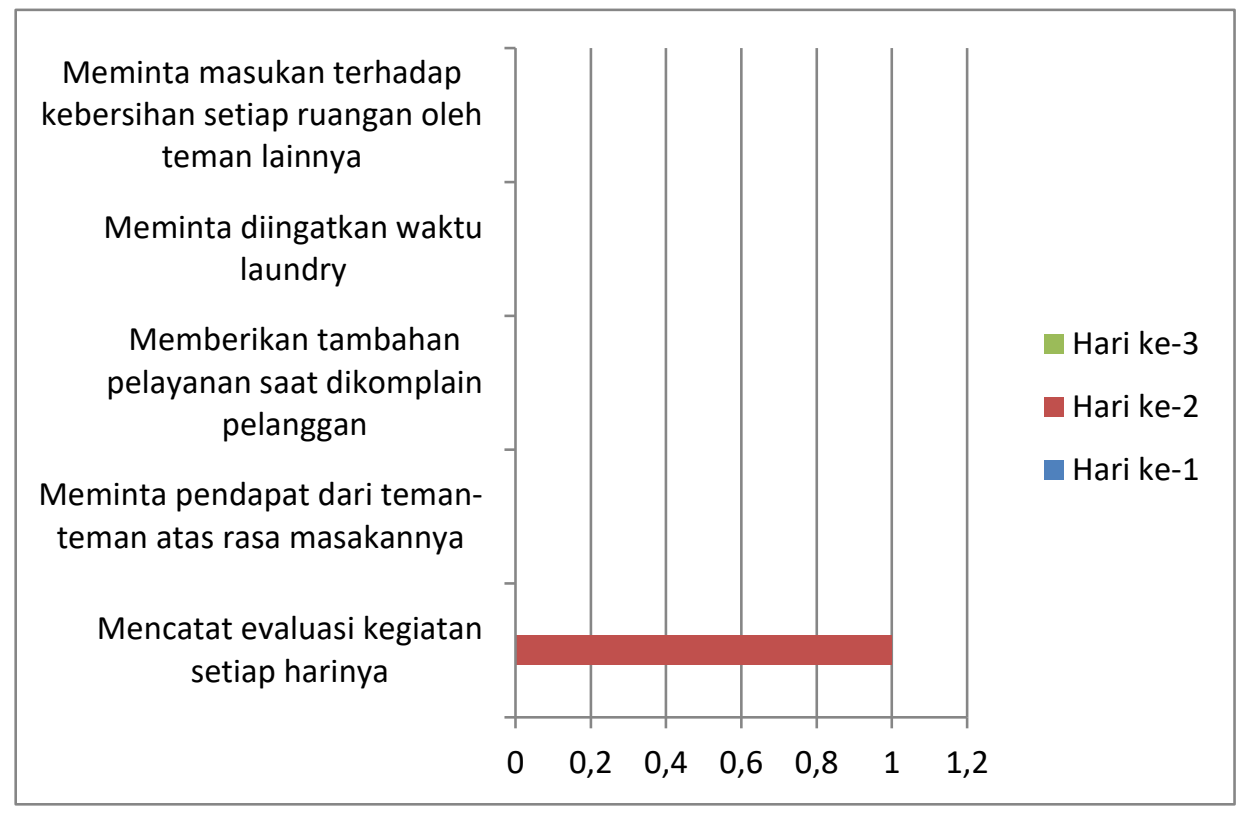

Gambar 2. Grafik sebaran frekuensi perilaku yang muncul berdasarkan dimensi Situation Redefinition

\section{c. Dimensi direct action}

Dimensi direct action atau dapat diartikan sebagai tindakan langsung dan dioperasionalisasikan sebagai bentuk coping dengan solusi langsung untuk masalah dengan mengetahui informasi tentang hal tersebut, atau benar-benar melakukan sesuatu untuk menyelesaikannya. Sesuai dengan hasil pengamatan yang disajikan pada gambar 3 dapat diketahui bahwa terdapat empat dari tujuh item perilaku yang diamati. Empat perilaku tersebut yakni membantu pekerjaan teman saat pekerjaan utamanya selesai, menggantikan posisi teman saat sedang keluar laboratorium, membantu teman 
yang sedang melayani pelanggan, dan membersihakn kembali ruang yang masih kotor. Diantara keempat perilaku yang muncul yakni perilaku menggantikan posisi teman yang sedang keluar laboratorium. Hal tersebut lebih banyak terjadi di hari kedua karena para teman lainnya ikut membantu memasarkan produk pisang coklat frozen di sekitar kampus. Mereka dalam prakteknya membagi tugas untuk sebagian berkeliling kampus dan sisanya menjaga laboratorium. Sedangkan perilaku yang muncul secara konsisten selama tiga hari proses pengamatan yakni perilaku Membantu pekerjaan teman saat pekerjaan utamanya telah selesai. Banyaknya tugas yang harus dikerjakan oleh mereka di dalam laboratorium membiasakan mereka untuk saling menolong satu sama lain. Perilaku tolong menolong tersebut hadir dari individu dengan kesadaran tinggi tanpa menyuruh satu sama lain. Kedekatan mereka selama tiga minggu berada di laboratorium MSDK telah membuat mereka lebih memahami peran dan beban teman kelompoknya.

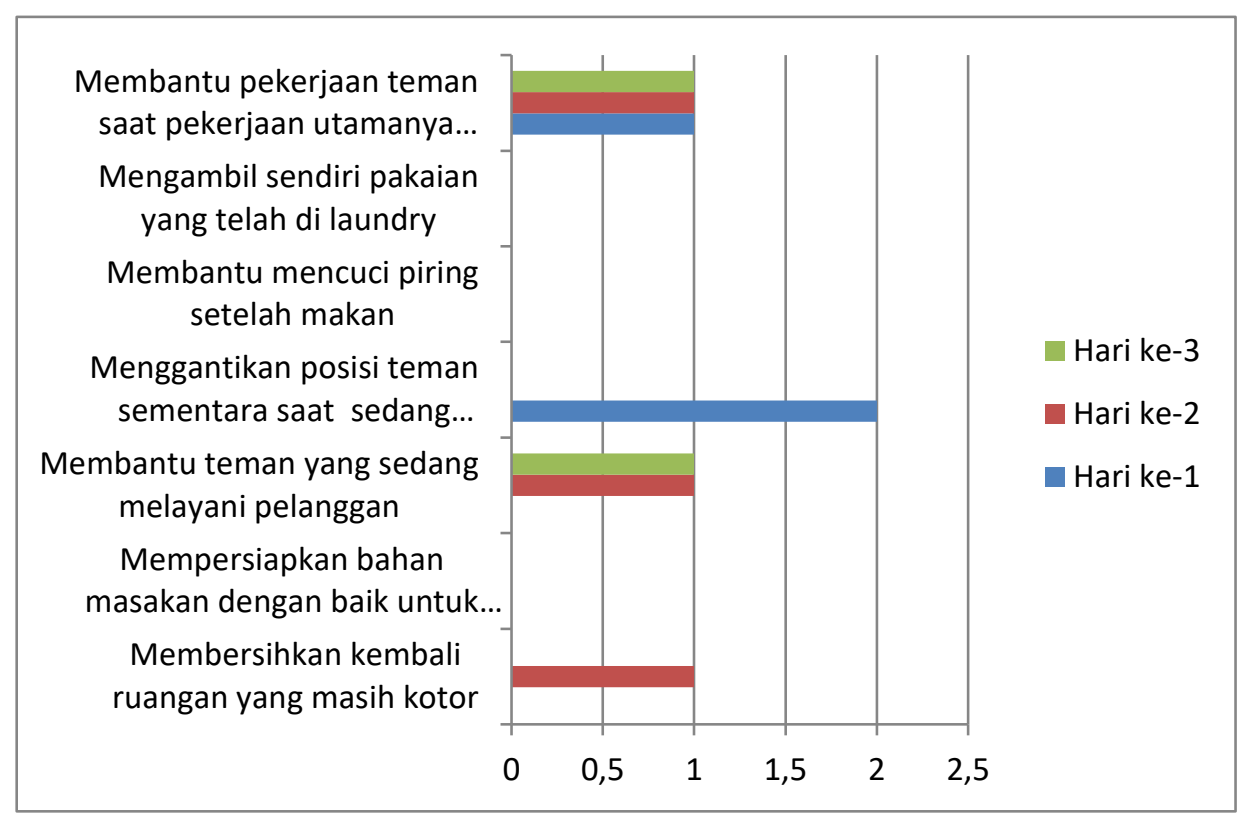

Gambar 3. Grafik sebaran frekuensi perilaku yang muncul berdasarkan dimensi Direct Action

\section{d. Dimensi catharsis}

Dimensi catharsis atau dapat diartikan sebagai katarsis atau pelampiasan dan dioperasionalisasikan sebagai bentuk coping dengan mengungkapkan emosi sebagai respons terhadap masalah untuk mengurangi ketegangan, kecemasan atau frustrasi. Merujuk pada gambar 4, grafik sebaran frekuensi menunjukan bahwa perilaku menggosip merupakan perilaku yang dominan menonjol dan banyak terjad di hari ketiga. Hal tersebut diakibatkan karena adanya kegiatan persiapan acara bakti sosial yang cukup melelahkan. Kegiatan yang melelahkan tersebut lebih banyak dimaknai sebagai sebuah "akal-akalan dosen". Ucapan yang tertangkap oleh peneliti dalam pengamatan dapat didefinisikan sebagai sebuah respon negatif akibat adanya kegiatan bakti sosial yang diadakan ditengah kegiatan MSDK. Mereka juga menganggap bahwa pemilihan waktu bakti sosial oleh dosen yang dilaksanakan pada malam hari merupakan sebuah pemilihan waktu yang kurang tepat. Sementara itu, perilaku menyanyi di sela kegiatan juga cukup konsisten ditangkap oleh peneliti. Kegiatan menyanyi yang dilakukan oleh para mahasiswa tersebut terjadi secara alamiah tanpa panduan atau ajakan dari teman lainnya. Menyanyi juga seringkali menjadi stimulus yang membuat mereka terlihat lebih bahagia dan puas terhadap kegiatan yang telah mereka kerjakan. Walaupun sebenarnya, indikator kepuasan dan kebahagiaan yang ditangkap oleh peneliti sebagai indikator yang sangat subjektif dan sangat dimungkinkan terdapat bias didalamnya. 


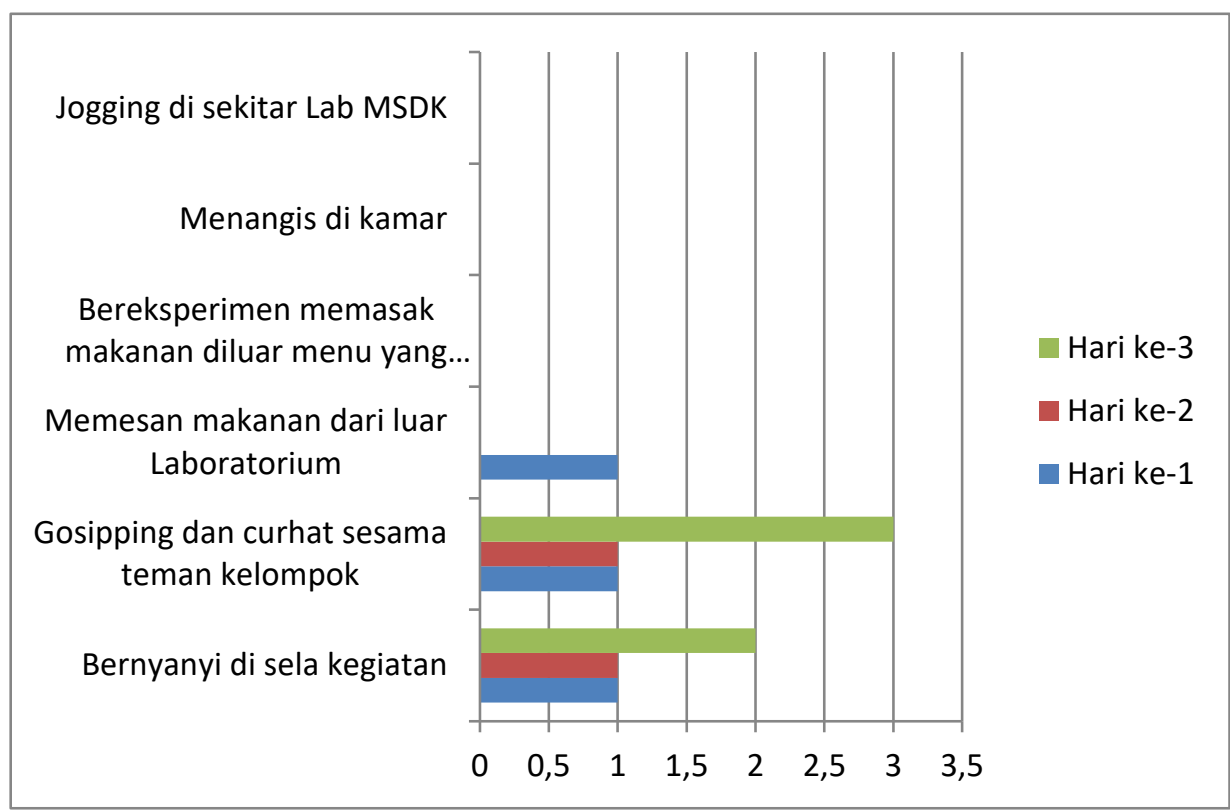

Gambar 4. Grafik sebaran frekuensi perilaku yang muncul berdasarkan dimensi Catharsis

\section{e. Dimensi acceptance}

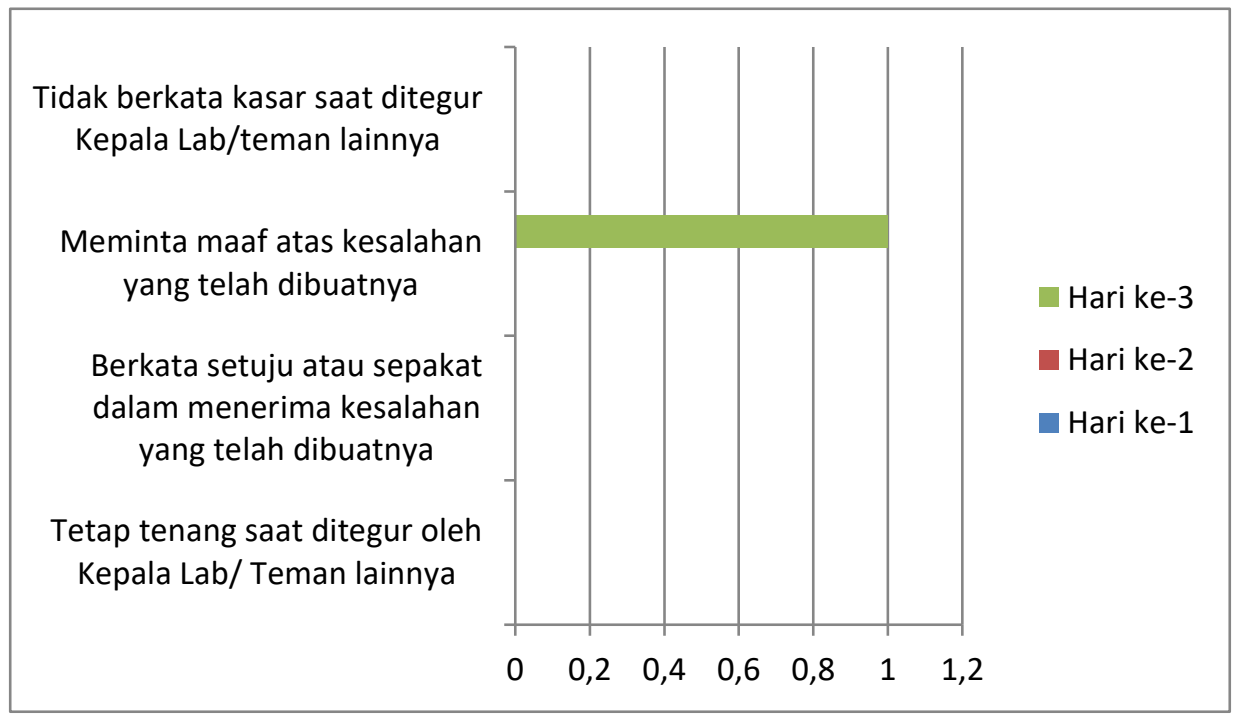

Gambar 5. Grafik sebaran frekuensi perilaku yang muncul berdasarkan dimensi Acceptance

Dimensi acceptance atau dapat diartikan sebagai penerimaan diri dan dioperasionalisasikan sebagai bentuk coping dengan menerima bahwa masalah telah terjadi, tapi tidak ada yang bisa dilakukan mengenai hal itu. Perilaku yang diukur dalam dimensi ini lebih banyak mengacu pada konteks reflektif yang terkadang dimunculkan oleh individu dalam menghadapi sebuah masalah. Upaya reflektif tersebut dalam konteks masalah yang muncul di praktikum MSDK sebenarnya mengacu pada sumber masalah utama yakni teguran yang berasal dari kepala laboratorium MSDK, dosen pembimbing dan teman sekelompoknya. Bisa dilihat pada gambar 5, menunjukan bahwa perilaku yang muncul hanyalah permintaan maaf yang ditujukan kepada teman sekelompoknya. Kemunculannya di hari ketiga disebabkan oleh adanya masalah kesalahpahaman dalam pelayanan makanan di kedai keluarga. Manager pada saat itu keliru dalam mencatat pesanan pelanggan hingga terjadi kekeliruan dalam penyajian menu yang dilakuan oleh cooking. Permintaan maaf yang sempat Jurnal Kesejahteraan Keluarga dan Pendidikan (JKKP) Vol.05 No.02 doi.org/10.21009/JKKP.052.02 
diamati oleh peneliti berlangsung pada suasana yang cukup kondusif hingga diduga tidak menimbulkan masalah baru selanjutnya. Sementara itu, ketidakhadiran kepala Lab.MSDK dan dosen pembimbing selama proses pengamatan menjadi penyebab utama tidak munculnya perilaku penerimaan diri dalam dimensi ini.

\section{f. Dimensi seeking social support}

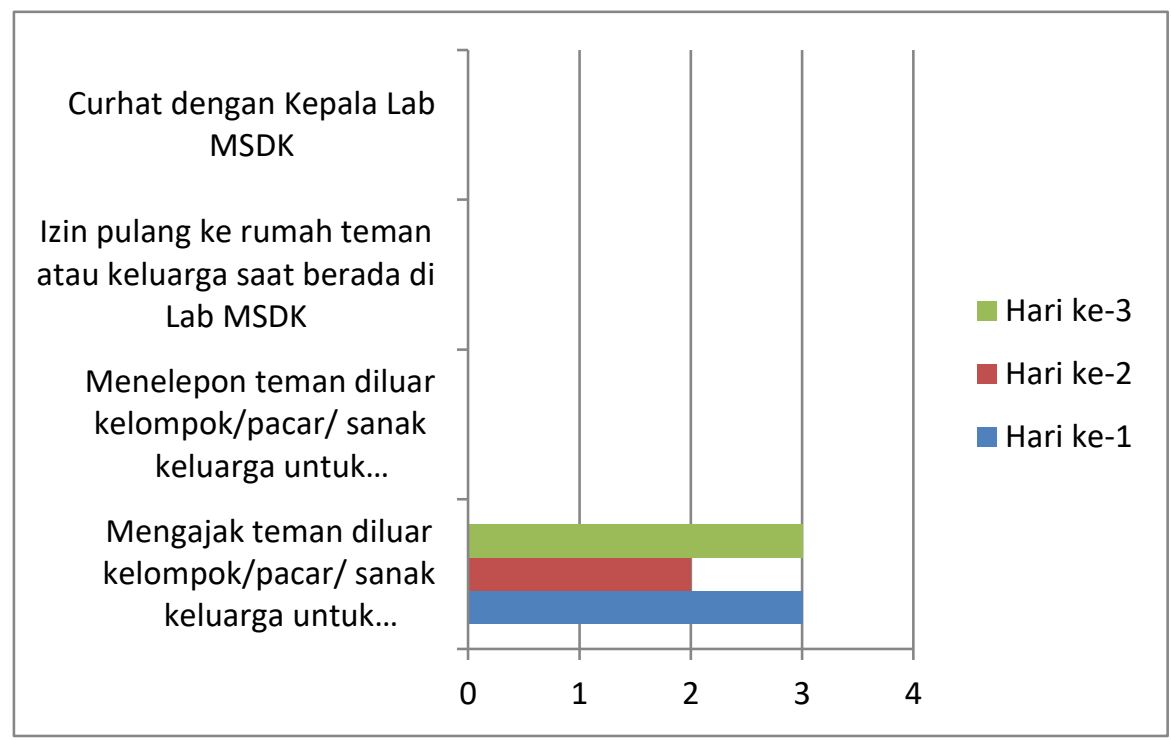

Gambar 6 Grafik sebaran frekuensi perilaku yang muncul berdasarkan dimensi Seeking Social Support

Dimensi seeking social support atau dapat diartikan sebagai mencari dukungan sosial dan dioperasionalisasikan sebagai bentuk coping dengan mencari atau menemukan dukungan emosional dari orang yang dicintai, teman, atau profesional. Individu lain dalam kehidupan memang seringkali memberikan kenyamanan dan dukungan disaat diri sedang menghadapi sebuah masalah. Individu tersebut biasanya dapat berupa teman, pacar, sanak saudara dan bahkan profesional seperti tokoh agama, guru, dosen, psikolog dan sebagainya. Kehadiran individu-individu tersebut di dalam praktikum MSDK merupakan suatu yang istimewa karena dapat dijadikan sebagai fasilitator sebagai ajang pencarian dukungan sosial dari eksternal. Para mahasiswa biasanya sering sekali mengajak pacar, teman bahkan sanak saudara untuk sekedar main dan mengunjungi mereka di sela-sela kegiatan. Walaupun terdapat peraturan MSDK yang membatasi adanya pertemuan tersebut, tetapi hal itu telah menjadi budaya dan kebiasaan yang sering dilakukan oleh semua mahasiswa yang sedang praktikum MSDK. Sesuai dengan fakta tersebut, hasil pengamatan pada gambar 6 juga menunjukan bahwa para mahasiswa secara konsisten dalam tiga hari pengamatan sering mengajak teman, pacar atau sanak saudara untuk mengunjungi mereka. Kegiatan yang biasa dilakukan ketika teman, pacar atau keluarga mereka datang pun beragam. Ada yang sekedar duduk dan mengobrol di kedai keluarga, menanyakan kabar dan membawakan makanan hingga foto bersama sebagai kenangkenangan. Raut wajah dan nada berbicara yang lebih bersemangat saat bertemu orang-orang tercinta mereka menandakan ada perasaan senang dan puas dari diri mereka.

\section{g. Dimensi relaxation}

Dimensi relaxation atau dapat diartikan sebagai relaksasi diri dan dioperasionalisasikan sebagai bentuk coping dengan melakukan sesuatu dengan niat implisit untuk bersantai. Sebagaimana gambar 7 dibawah ini, diketahui bahwa hanya item bersenandung saat menyiram tanaman dan jalan-jalan ke mall terdekat yang tidak muncul selama pengamatan. Sedangkan item perilaku lainnya muncul Jurnal Kesejahteraan Keluarga dan Pendidikan (JKKP) Vol.05 No.02 doi.org/10.21009/JKKP.052.02 
dengan frekuensi yang beragam. Adapun perilaku menonton film drama korea dan bercanda dan tertawa bersama teman merupakan perilaku dengan frekuensi terbanyak yang muncul. Hal tersebut dikarenakan tidak ada hadirnya kepala Lab MSDK atau dosen pembimbing. Tidak adanya orang lain yang memiliki otoritas kuat dalam sebuah setting perilaku dapat membuat individu merasa lebih bebas dan bersenang-senang. Selain itu, perilaku berbaring di kamar merupakan hal yang juga sering ditemui oleh peneliti. Meskipun sebenarnya dalam proses pengamatan, peneliti sangat terbatas untuk memastikan apa yang dilakukan individu saat berada di dalam kamar. Namun, pada akhirnya peneliti mengasosiasikan keberadaan mereka saat di dalam kamar masuk dalam perilaku berbaring.

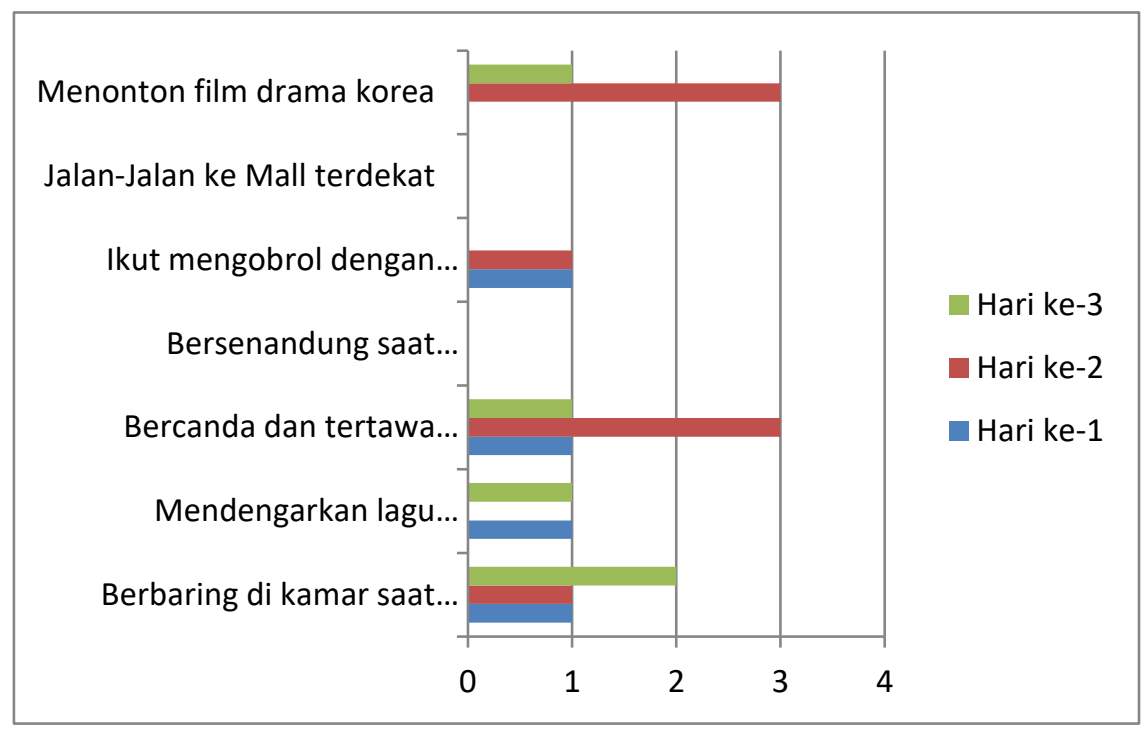

Gambar 7. Grafik sebaran frekuensi perilaku yang muncul berdasarkan dimensi Relaxation

\section{h. Dimensi religion}

Dimensi religion atau dapat diartikan sebagai kegiatan religiusitas atau keagamaan dan dioperasionalisasikan sebagai bentuk coping dengan mencari atau menemukan kenyamanan dan dukungan spiritual. Tidak satupun perilaku yang muncul dalam dimensi ini disebabkan oleh terbatasanya ruang gerak peneliti selama proses pengamatan. Hal tersebut dikarenakan semua mahasiswa yang sedang melakukan praktikum MSDK merupakan perempuan dan memiliki privasi dan hak untuk melakukan kegiatannya seputar keagamaan di dalam kamar. Meskipun wording dijadikan sebagai alat bantu peneliti untuk menemukan perilaku dalam dimensi ini, namun perilaku religius yang dikonstruksi dalam alat ukur observasi ini tidak sama sekali muncul. Oleh karena itu, gender peneliti dan subjek yang diobservasi menjadi salah satu limitasi dalam pengamatan ini.

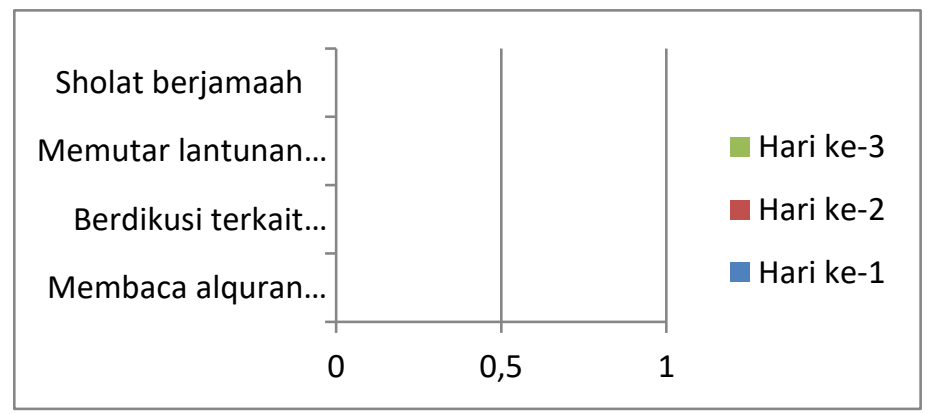

Gambar 8. Grafik sebaran frekuensi perilaku yang muncul berdasarkan dimensi Religion

\section{Diskusi}

Jurnal Kesejahteraan Keluarga dan Pendidikan (JKKP) Vol.05 No.02 doi.org/10.21009/JKKP.052.02 


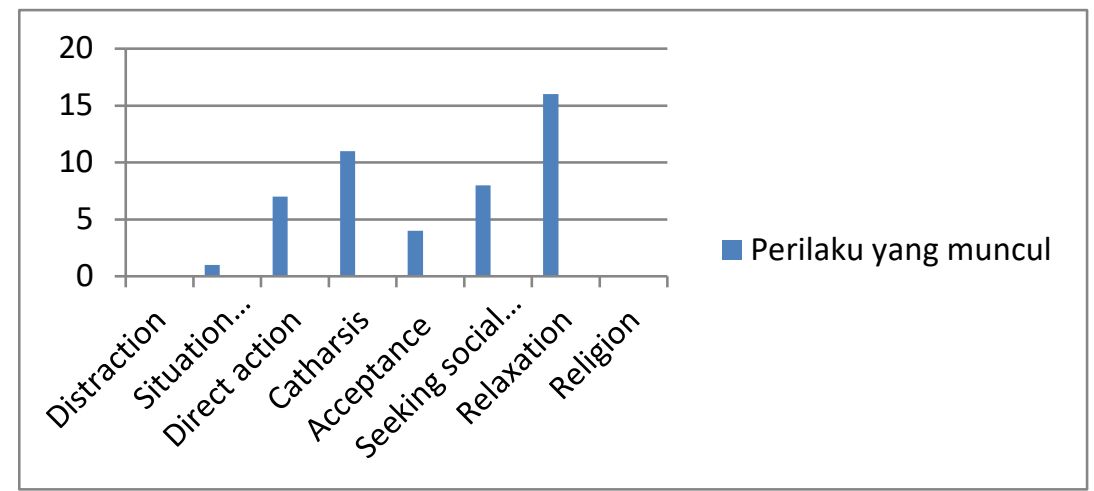

Gambar 9. Grafik sebaran frekuensi perilaku yang muncul secara akumulatif

Perilaku daily coping yang dikonstruksi oleh Stone dan Neale (1984) menggambarkan bahwa terdapat delapan dimensi yang muncul untuk menghadapi sebuah masalah dalam kehidupan seharihari. Delapan dimensi tersebut yakni distraction, situation redefinition, direct action, catharsis, acceptance, seeking social support, relaxation dan religion. Merujuk pada gambar 9 diketahui bahwa para kelompok mahasiwa yang sedang melakukan praktikum di laboratorium MSDK lebih banyak memunculkan perilaku daily coping dalam dimensi relaxation dan catharsis. Sementara itu, hasil pengamatan juga menunjukan tidak adanya perilaku daily coping yang muncul dari dimensi distraction dan religion.

Tingginya frekuensi perilaku daily coping pada dimensi relaxation lebih banyak ditunjukan pada hari kedua (lihat gambar 10). Hal tersebut dikarenakan pada hari kedua masalah yang muncul lebih sedikit dibandingkan hari pertama. Sementara itu, hari kedua pengamatan bertepatan pada hari jumat atau hari terakhir mereka di MSDK. Sesuai peraturan MSDK yang terbaru tahun 2018, setiap kelompok diwajibkan pulang kerumah masing-masing setiap jumat malam dan harus kembali lagi ke laboratorium MSDK pada minggu malam. Suasana akhir minggu sepertinya dianggap sebagai hari pelepas penat oleh mereka. Oleh karena itu, kemunculan frekuensi perilaku relaksasi lebih banyak terdapat di hari jumat.

Berdasarkan gambar 10. Juga menunjukan bahwa frekuensi perilaku katarsis sebagai salah satu dimensi pada daily coping behavior lebih banyak muncul pada hari ketiga atau hari senin. Hal tersebut bertolak belakang dengan perilaku relaksasi yang lebih banyak muncul di hari jumat. Hal tersebut dikarenakan pada hari senin, tekanan harus mereka hadapi kembali mengingat pada malam harinya akan diadakan kegiatan bakti sosial. Pagi hari hingga siang harinya mereka lebih banyak menggunakan waktunya untuk mempersiapkan acara bakti sosial seperti membagi tugas belanja, membungkus parsel dan mengurus keuangan. Kegiatan tersebut dalam pengamatan peneliti telah memunculkan bentuk coping nyata yakni gossiping dan tertawa bersama di sela kegiatan (lihat juga gambar 4).

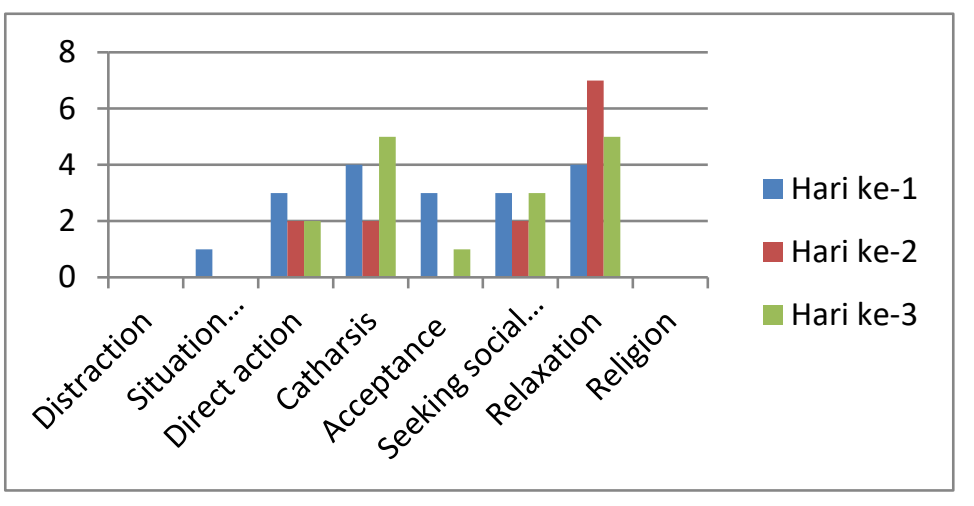

Gambar 10. Grafik sebaran frekuensi perilaku yang muncul berdasarkan seluruh dimensi 
Pascual, Conejero dan Extebarria (2016) meneliti sekitar 762 responden di Spanyol untuk melihat perbedaan strategi coping berdasarkan gender. Dari penelitian tersebut diperoleh hasil yang menunjukan bahwa perempuan lebih kuat menggunakan emotional expression sebagai strategi coping dibandingkan dengan laki-laki. Sebaliknya, penelitian oleh Monteiro, Balogun dan Oratile (2014) di Bostwana menunjukan tidak ada perbedaan yang signifikan pada coping strategi antara lakilaki dan perempuan. Penelitian tersebut berhubungan dengan subjek pengamatan pada makalah ini. Subjek pengamatan yang semuanya adalah perempuan menunjukan lebih banyaknya bentuk daily coping yang bersifat emotional based. Hal itu ditujukan dengan tingginya frekuensi perilaku pada dimensi catharsis dan relaxation pada kelompok mahasiswa PVKK UNJ yang sedang mengikuti praktikum

\section{KESIMPULAN}

Berdasarkan pengamatan yang telah dilakukan, peneliti menarik kesimpulan bahwa daily coping yang ditunjukan oleh para mahasiswa PVKK UNJ yang sedang mengikuti praktikum MSDK sangat dipengaruhi oleh faktor gender. Adapun limitasi dalam pengamatan ini terletak pada dosen dan Kepala Lab yang tidak hadir saat observasi. Hal tersebut memberikan kontribusi pada frekuensi perilaku daily coping yang muncul sebagai akibat dari stresor yang telah diprediksi sebelumnya. Selanjutnya pengamatan selanjutnya diharapkan observer untuk ikut menginap di Lab. MSDK untuk menemukan lebih banyak perilaku yang dapat diamati. Selain itu, dalam pengamatan observer hanya terbatas berada di ruang tamu dan ruang makan, karena semua partisipan adalah perempuan. Sementara itu, konstruk perilaku dalam lembar observasi ini disesuaikan hanya untuk subjek yang jumlahnya sedikit dan mudah diamati, kedepannya perlu dikontruksi untuk subjek pengamatan yang lebih besar (kelompok besar).

\section{REFERENSI}

Coyne, J., Aldwin, C., \& Lazarus RS. 1981. Depression and Coping In Stressfull Episodes. Jurnal Of Abnormal Psichology. Vol. 50.

Friedman-Wheeler, D. G., Pederson, J. E., Rizzo-Busack, H. M., \& Haaga, D. A. (2016). Measuring Outcome Expectancies for Specific Coping Behaviors: the Coping Expectancies Scale (CES). Journal of Psychopathology and Behavioral Assessment, 38(3), 421-432.

Gunthert, K. C., Cohen, L. H., \& Armeli, S. (1999). The role of neuroticism in daily stress and coping. Journal of Personality and Social Psychology, 77(5), 1087-1100.

Indrawati, Herlina \& Misbach .(2017). Handout kuliah psikodiagnostik II. Jurusan Psikologi Universitas Pendidikan Indonesia

Kloos, B., Hill, J., Thomas, E., Wandersman, A., Elias, M. J., \& Dalton, J. H. (2012). Community psychology: Linking individuals and community. Wadswort: Cengage Learning.

Latack, J. C., \& Havlovic, S. J. (1992). Coping with job stress: A conceptual evaluation framework for coping measures. Journal of organizational behavior, 13(5), 479-508.

Monteiro, N. M., Balogun, S. K., \& Oratile, K. N. (2014). Managing stress: the influence of gender, age and emotion regulation on coping among university students in Botswana. International journal of adolescence and youth, 19(2), 153-173.

Pascual, A., Conejero, S., \& Etxebarria, I. (2016). Coping strategies and emotion regulation in adolescents: Adequacy and gender differences. Ansiedad y Estrés, 22(1), 1-4.

Stone, A. A., \& Neale, J. M. (1984). New measure of daily coping: Development and preliminary results. Journal of personality and social psychology, 46(4), 892.

Tim Penyusun Fakultas Teknik (2016). Buku pedoman akademik 2016/2017 Fakultas Teknik Universitas Negeri Jakarta. Universitas Negeri Jakarta

Wibowo, I., Pelupessy, D., \& Narhetali, E. (2011). Psikologi komunitas. Depok: LPSP3 UI 